\title{
PERANCANGAN WEBSITE SARANA PROMOSI FAKULTAS TEKNIK UNIVERSITAS ASAHAN BERBASIS WEB MOBILE
}

\author{
Lius Boyke Panjaitan \\ Fakultas Teknik Jurusan Teknik Informatika Universitas Asahan \\ Jl. Jend Ahmad Yani Kisaran Sumatera Utara \\ liusboyke@gmail.com
}

\begin{abstract}
ABSTRAK
Abstrak - Fakultas Teknik merupakan salah satu dari lima Fakultas yang ada di kampus Universitas Asahan yang merupakan tempat peneliti melakukan penelitian yang memiliki tiga jurusan diantaranya Jurusan Teknik Sipil, Teknik Informatika, Teknik Mesin, saat ini Fakultas Teknik tidak memiliki layanan promosi ke masyarakat ini yang menyebabkan tidak tersampainya informasi kepada kalangan masyarakat. Website media promosi Fakultas Teknik dirancang untuk menampilkan informasi, teks, gambar atau gabungan dari semuanya itu, baik yang bersifat statis maupun dinamis yang membentuk satu rangkaian sistem yang saling berkait dimana masing masing dihubungkan dengan halaman menu yang ada di website. Sistem ini merupakan sistem berbasis web yang dikembangkan dengan menggunakan metode prototype merupakan metode berorientasi objek. Pendekatan fungsional yang digambarkan pada sistem menggunakan UML (Unified Modeling Language).Hasil penelitian menunjukkan bahwa perangkat lunak yang dibangun dapat memberikan informasi yang di butuhkan dengan baik. Dengan demikian, aplikasi ini dapat digunakan sebagai media promosi Fakultas Teknik Universitas Asahan Kata Kunci - Media Promosi, Fakultas Teknik, Universitas Asahan, Web
\end{abstract}

\section{PENDAHULUAN}

\section{A. Latar BelakangMasalah}

Pesatnya perkembangan teknologi informasi pada saat ini sangat cepat dan hampir menyeluruh setiap bidang. Salah satu bidang yang tidak dapat terlepas dari teknologi informasi adalah bidang pendidikan. Dengan memanfaatkan perkembangan teknologi informasi di bidang pendidikan akan menjadikan pendidikan pada saat ini bisa menjadi lebih baik dan update.

Media promosi merupakan sarana yang digunakan untuk mengkomunikasikan suatu produk /jasa/image/perusahaan ataupun yang lain untuk dapat lebih dikenal masyarakat lebih luas. Dimana dengan promosi ini diharapkan seseorang bisa mengetahui, mengakui, memiliki, dan mengikatkan diri pada suatu barang/jasa/produk/image/perusahaan yang menjadi sasarannya. Salah satu bagian penting dari promosi adalah menentukan media promosi yang paling tepat. Misalnya Surat Kabar, Televisi, Radio, Majalah, dan lain-lain.

Fakultas Teknik merupakan salah satu dari lima Fakultas yang ada di kampus Universitas Asahan yang merupakan tempat peneliti melakukan penelitian yang memiliki tiga jurusan diantaranya Jurusan Teknik Sipil, Teknik Informatika, Teknik Mesin. Permasalahan saat ini Fakultas Teknik tidak memiliki layanan promosi ke masyarakat atau sekolah-sekolah dalam bentuk web ini yang menyebabkan tidak tersampainya informasi kepada kalangan masyarakat.

\section{B. Rumusan Masalah}

Berdasarkan uraian latar belakang masalah maka perumusan masalah penelitian adalah sebagai berikut :

1. Bagaimana rancangan dari website sarana promosi Fakultas Teknik Universitas Asahan berbasis web mobile yang akan dibangun? .

2. Bagaimana sistem penyampain aktivitas yang dilakukan Fakultas Teknik ke kalangan masyarakat?.

3. Bagaimana proses dokumentasi dari aktivitas Fakultas Teknik yang diterapkan oleh Fakultas Teknik?

\section{LANDASAN TEORI}

A. Sistem

Sistem meupakan suatu jaringan kerja dari prosesdur-prosedur yang saling berhubungan, berkumpul dan bersama-sama untuk melakukan suatu kegiatan atau untuk menyelesaikan suatu sasaran tertentu. Sistem terdiri dari sejumlah komponen yang saling berinteraksi, saling bekerja sama membentuk satu kesatuan. Komponen-komponen sistem atau elemen-elemen sistem dapat berupa suatu sub sistem atau bagian-bagian dari sistem. Setiap sub sistem mempunyai sifat-sifat dari sistem untuk menjalankan suatu fungsi tertentu dan mempengaruhi proses sistem secara keseluuhan (Anastasia Lipursari, 2013). 


\section{B. Aplikasi}

Aplikasi bisa dijumpai pada berbagai bidang dan digunakan untuk menangani berbagai aktivitas. Aplikasi dapat berupa desktop dibuat dengan menggunakan berbagai perkakas pengembangan dan umumnya bergantung secara sepesifik terhadap platform yang digunakan. Dilingkungan windows, aplikasi bisa dibangun dengan visual basic, dhelpi, atau semacam itu. Dilingkungan linux , aplikasi dibuat dengan menggunakan C++, Gambas (Abdul Kadir, 2014 : 22).

\section{Aplikasi Mobile}

Menurut Muhdar Abdurahman, (2016) yang dikutip dari (Reza B'Far, 2005:3). Aplikasi mobile dapat diartikan sebagai sebuah produk dari sistem komputasi mobile, yaitu system komputasi yang dapat dengan mudah dipindahkan secara fisik dan yang komputasi kemampuan dapat digunakan saat mereka sedang dipindahkan. Contohnya adalah personal digital assistant (PDA), smartphone dan ponsel. Berdasarkan jenisnya, Brian Fling (2009:70) membagi aplikasi mobile menjadi beberapa kelompok yaitu:

1. Short Message Service (SMS) Merupakan aplikasi mobile paling sederhana, dirancang untuk berkirim pesan dan berguna ketika terintegrasi dengan jenis aplikasi mobile lainnya.

2. Mobile Websites (Situs Web Mobile) Merupakan situs web yang dirancang khusus untuk perangkat mobile. Situs web mobile sering memiliki desain yang sederhana dan biasanya bersifat memberikan informasi.

3. Native Application (Aplikasi Asli) Merupakan aplikasi mobile yang harus diinstal pada perangkat target. Aplikasi ini dapat disebut aplikasi platform, karena aplikasi ini harus dikembangkan dan disusun untuk setiap platform mobile secara khusus.

\section{Aplikasi Web Mobile}

Mobile Web Application (Aplikasi Web Mobile) Aplikasi web mobile merupakan aplikasi mobile yang tidak perlu diinstal atau dikompilasi pada perangkat target, aplikasi ini mampu memberikan pengguna pengalaman layaknya aplikasi native/asli. Adapun aplikasi yang digunakan untuk perancangan aplikasi web mobile antara lain sebagai berikut (Muhdar Abdurahman, 2016)

\section{XHTML. \\ 2. CSS. \\ 3. JavaScript}

\section{E. $U M L$}

UML (Unified Modeling Language) merupakan sebuah notasi grafis, yang di dukung oleh metode tunggal, yang membantu dalam menggambarkan dan merancang sistem perangkat lunak, khususnya sistem perangkat lunak yang dibangun dengan modelberorientasi objek (Riska Audina, 2015).

\section{F. Web atau Situs}

Website atau situs dapat diartikan sebagai kumpulan halaman halaman yang digunakan untuk menampilkan informasi, teks, gambar diam atau bergerak, animasi, suara, dan atau gabungan dari semuanya itu, baik yang bersifat statis maupun dinamis yang membentuk satu rangkaian bangunan yang saling berkait dimana masing masing dihubungkan dengan jaringan jaringan halaman (Yadi Utama, 2011).

\section{METODOLOGI PENELITIAN}

\section{A. Rancangan Penelitian}

Untuk menyusun penelitian ini, dilakukan penerapan metode penelitian dalam memperoleh data-data yang dibutuhkan sehingga penyusunan penelitian ini dapat diselesaikan dengan baik, dan sistematis.

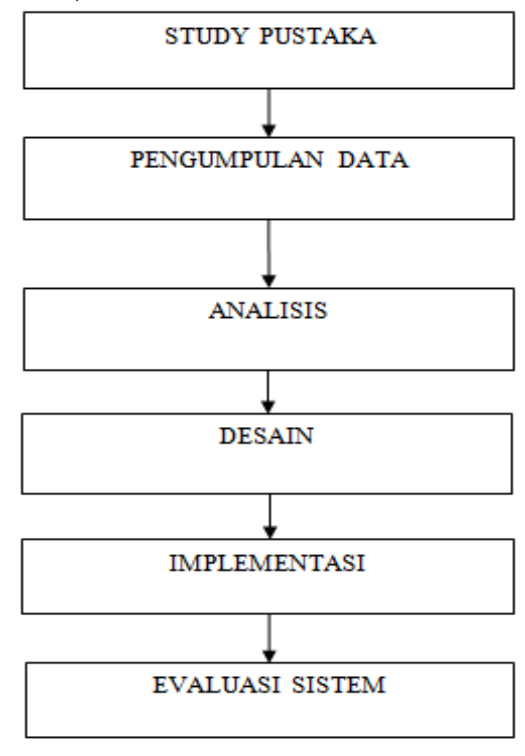

Gambar 1. Kerangka Kerja

\section{B. Metode Penelitian}

Dalam pembuatan aplikasi ini, metode yang penulis gunakan berupa metode Observasi, 
yang nantinya digunakan untuk memperoleh datadata yang dibutuhkan dalam pembuatan aplikasi. Metode observasi ini berupa pengumpulan data dari sumber-sumber yang berkaitan dengan perancangan aplikasi, antara lain seperti kegiatankegiatan yang dilakukan Fakultas Teknik, sehingga nantinya aplikasi yang dihasilkan dapat benar-benar memberikan manfaat pada penggunanya.

\section{Obyek Penelitian}

Objek penelitian merupakan permasalahan yang diteliti. Objek dari penelitian ini adalah bagaimana membangun sebuah aplikasi pada perangkat lunak web mobile tentang kegiatan yang dilakukan Fakultas Teknik guna sebagai media promosi ke kalangan masyarakat umum. Penelitian ini berdasarkan tempat dan waktu, seperti sistem yang dibutuhkan dalam pembuatan aplikasi.

\section{ANALISA DAN PEMBAHASAN}

\section{A. Analisa Masalah}

Dalam melakukan pem-bangunan aplikasi ini terdapat beberapa masalah dan faktor penting yang perlu diperhatikan yaitu mengenai permasalahan bagaimana masyarakat dapat mengetahui bahwa di Universitas Asahan memiliki Program Studi Teknik Informatika yang suda lama ada di Kabupaten Asahan. Hasil analisa ini akan dijadikan sebagian acuan dalam pembangunan website sarana promosi Fakultas Teknik Universitas Asahan berbasis web mobile.

\section{B. Perancangan Sistem Dengan UML}

Perancangan proses yang akan dibangun akan ditampilkan dalam bentuk logic model dengan menggunakan UML (Unified Modelling Language). Berikut ini perancangan dengan menggunakan UML.

\section{Use Case}

Use case merupakan fungsionalitas dari suatu sistem, sehingga user atau aplikasi dapat mengerti mengenai aplikasi yang akan dibangun. Use Case aplikasi dapat dilihat dalam gambar dibawah ini.

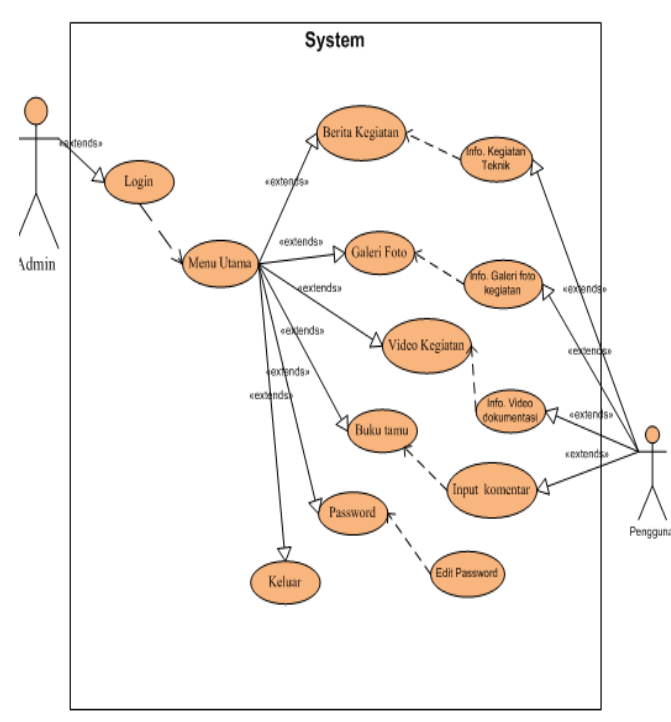

Gambar 2. Use Case

\section{Class Diagram}

Class diagram menggambarkan struktur sistem dari segi pendefinisian kelas-kelas yang akan dibuat untuk membangun sistem. Class diagram yang diusulkan sebagai berikut

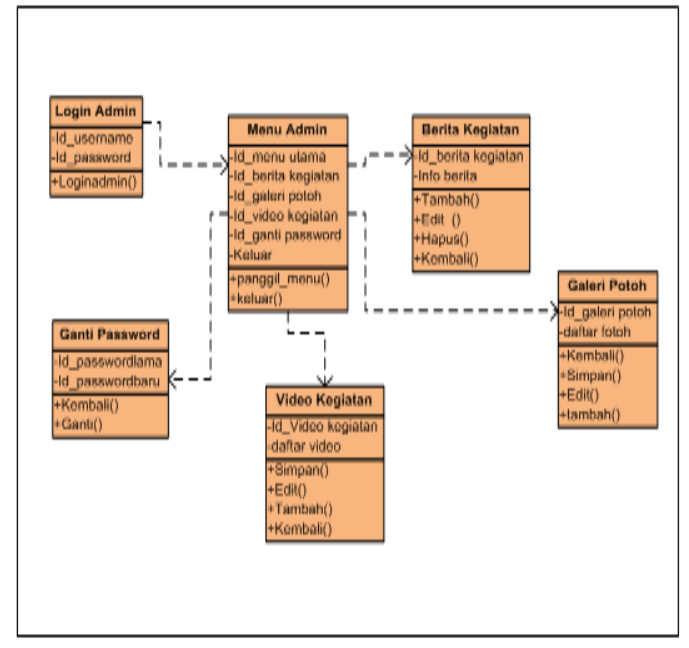

Gambar 3. Class Diagram

\section{E. Implementasi Sistem}

Implementasi sistem terdiri dari implementasi admin dan implementasi pengguna.

1. Implementasi admin

a. Implementasi Menu Utama

Terlebih dahulu, admin login dengan menggunakan username dan password misalnya untuk username admin dan password admin. Dengan mengetikkan http://promosi/admin/ setelah proses login berhasil maka sistem akan menuju menu utama seperti gambar dibawah ini. 


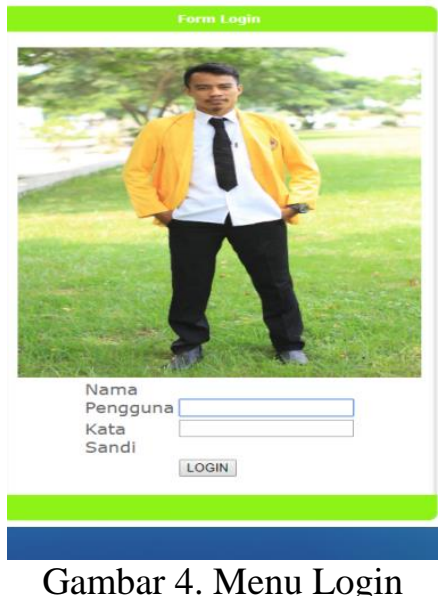

Gambar 4. Menu Login

Gambar di atas merupakan tampilan dari menu login pada aplikasi yang dirancang, input username dan kata sandi admin kemudian klik login maka akan tampil menu di bawah ini.

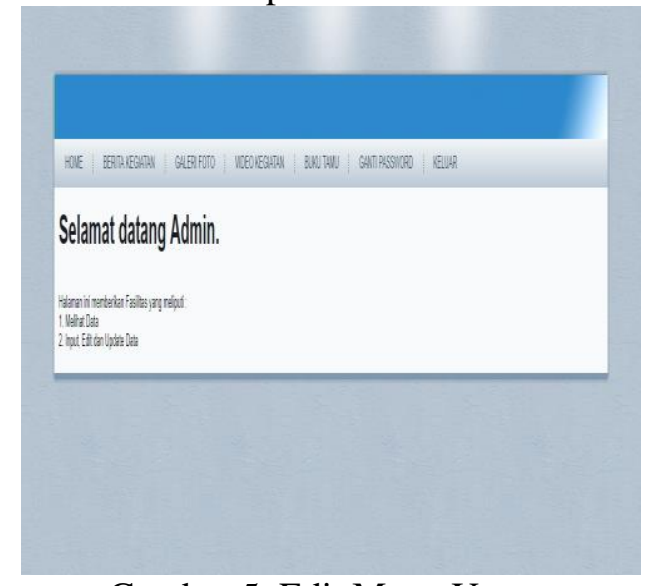

Gambar 5. Edit Menu Utama

Setelah berhasil masuk ke menu utama selanjutnya memilih menu berita kegiatan untuk menginput data berita kegiatan Fakultas Teknik, maka akan tampil halaman menu berita kegiatan seperti terlihat pada gambar dibawah ini.

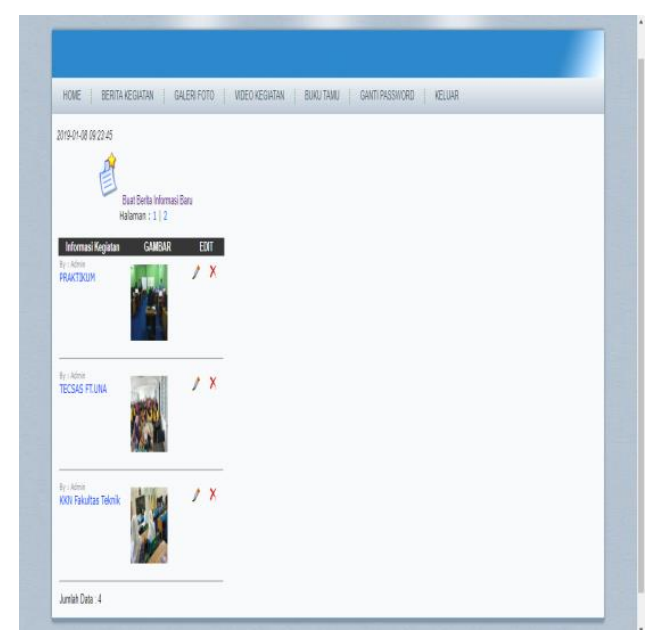

Gambar 6. Edit Berita
Untuk menambahkan Poto dokumentasi Fakultas Teknik admin bisa menambahnya di menu galleri Poto selanjutnya input Poto, tampilan menunya seperti yang terlihat dibawah ini .

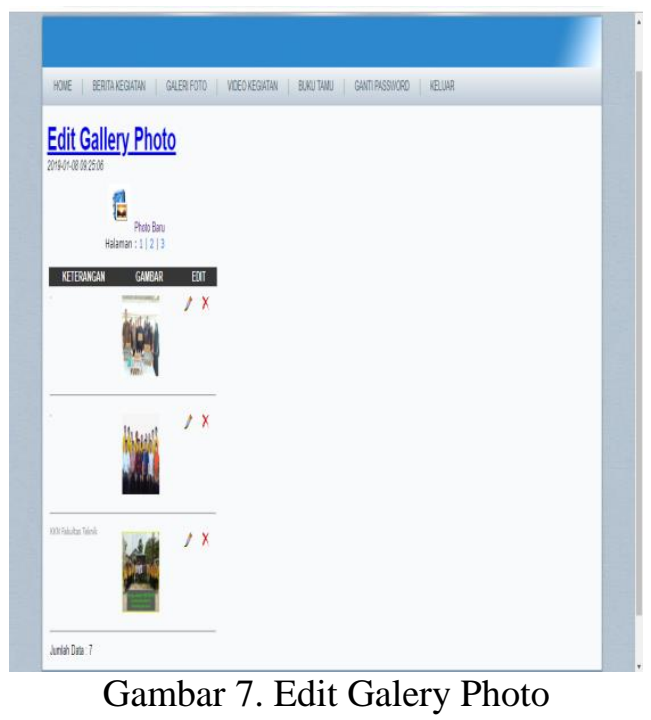

Untuk Menambah video kegiatan Fakultas Teknik admin bisa menambahnya di menu video kegiatan, menu tersebut terlihat seperti di bawah ini.

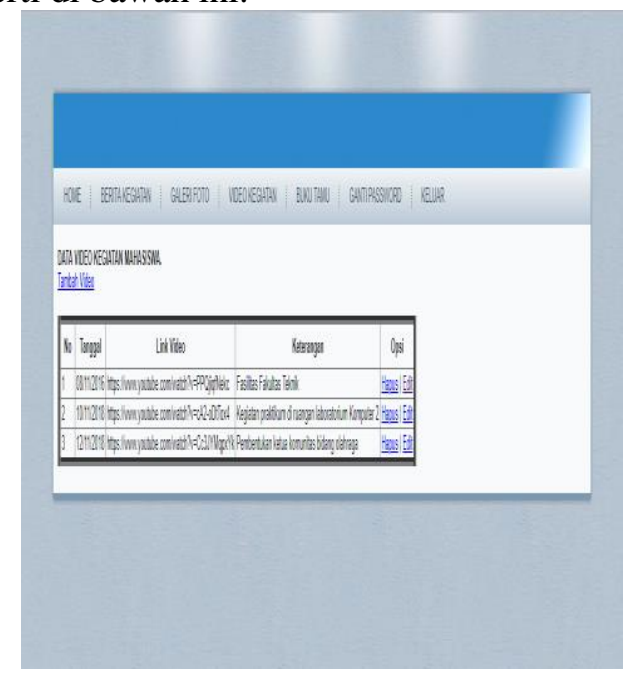

Gambar 8. Edit Data Video

Untuk melihat komentar pengguna admin bisa membuka menu buku tamu pada menu utama admin maka hasil menunya akan terlihat pada gambar dibawah ini. 


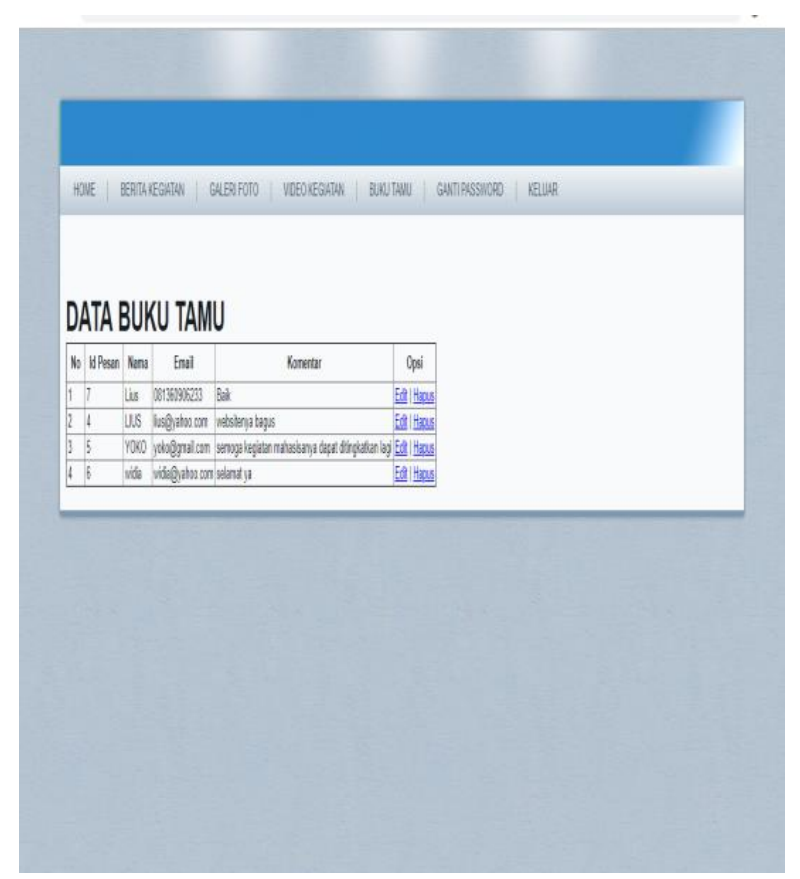

Gambar 9. Edit Buku Tamu

Untuk mengganti password admin pilih menu ganti password selanjutnya ganti password maka hasil menunya akan terlihat pada gambar dibawah ini.

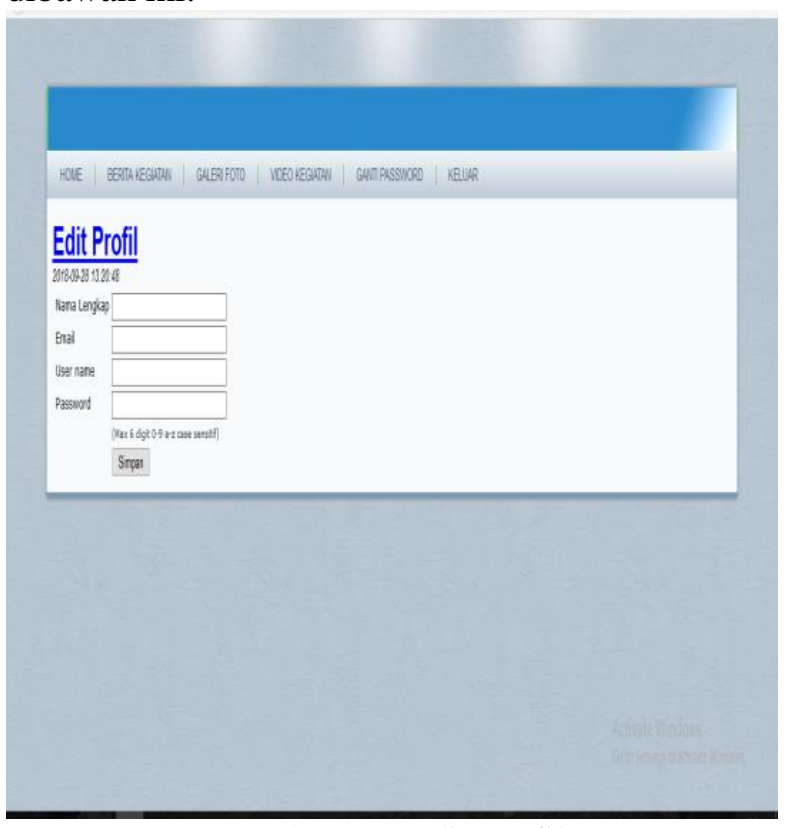

Gambar 10. Edit Profil

\section{b. Implementasi Pengguna}

Terlebih dahulu, pengguna membuka aplikasi dengan mengetikkan http://promosi/ maka hasil seperti gambar dibawah ini.

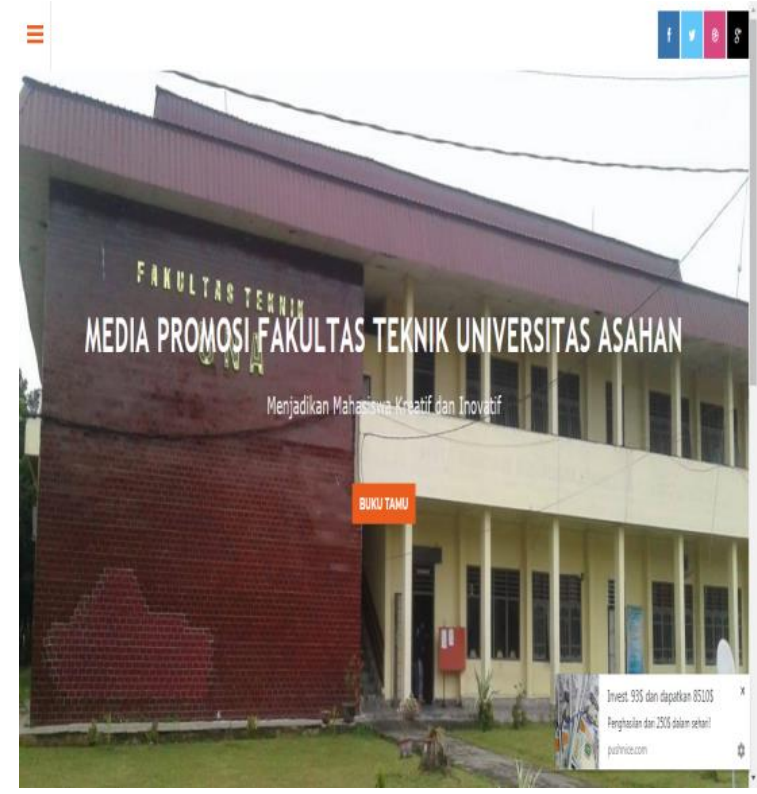

Gambar 11. Halaman Utama

Untuk melihat berita kegiatan yang pernah dilakukan Fakultas Teknik pilih menu berita kegiatan selanjutnya maka hasil menunya akan terlihat pada gambar di bawah ini.

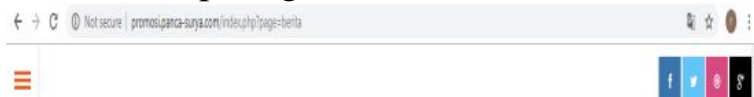

三

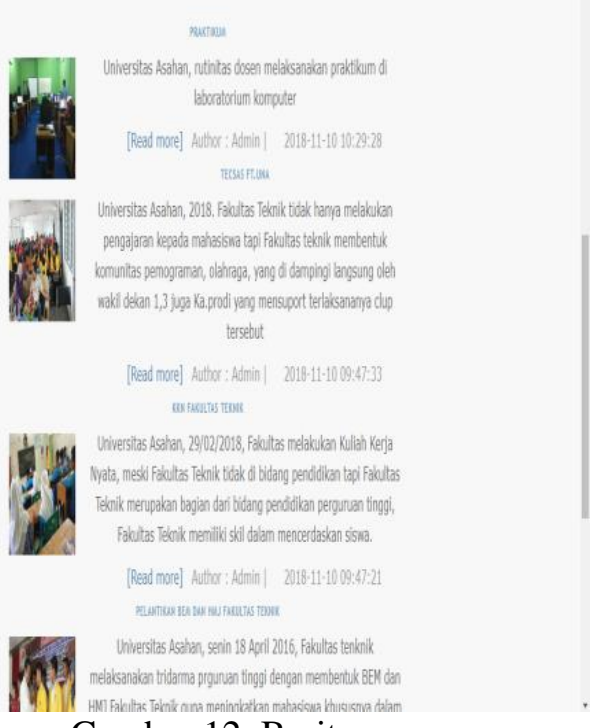

Gambar 12. Berita

Untuk melihat Poto kegiatan-kegiatan Fakultas Teknik pengguna bisa membuka menu galleri Poto maka sistem akan menuju ke galleri Poto seperti gambar di bawah ini. 


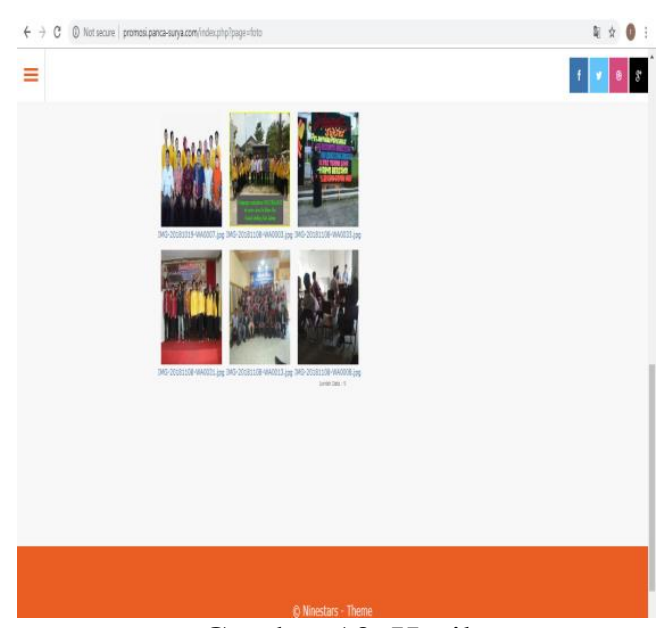

Gambar 13. Hasil

Untuk melihat video kegiatan Fakultas Teknik pengguna bisa langsung membuka menu video kegiatan maka hasil menunya terlihat seperti gambar di bawah ini.

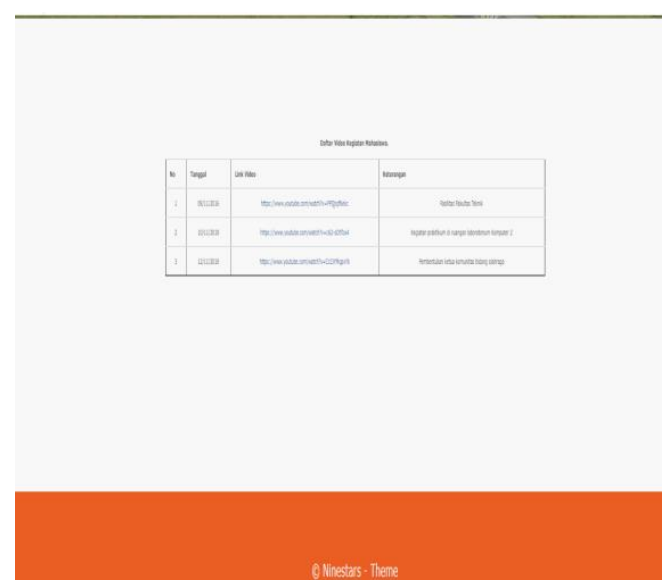

Gambar 14 Daftar Kegiatan

Untuk mengisi komentar pengguna bisa langsung membuka menu buku tamu pada menu utama maka hasil menunya terlihat seperti gambar di bawah ini.

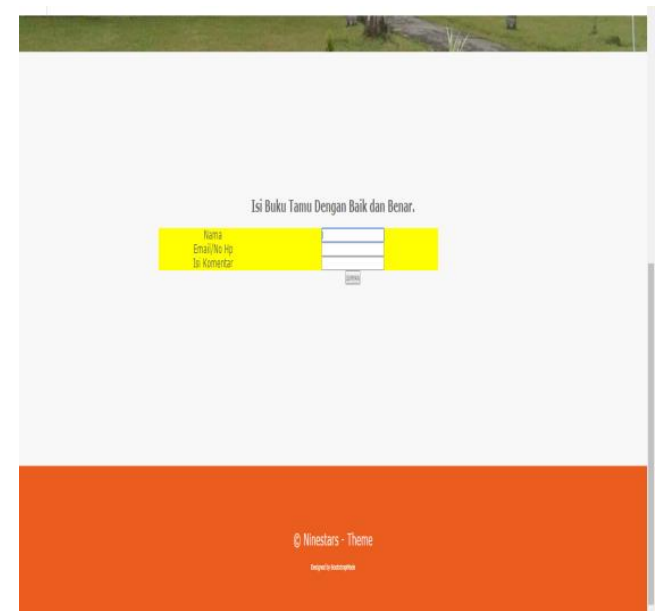

Gambar 15. Buku Tamu pada Menu Utama

\section{PENUTUP}

Kesimpulan

Dari hasil pembahasan pada bab-bab yang telah diuraikan sebelumnya, maka penulis mengambil kesimpulan sebagai berikut :

1. Untuk rancangan dari website sarana promosi Fakultas Teknik Universitas Asahan berbasis web mobile yang akan dibangun, penulis membuat aplikasinya dengan tampilan yang mudah dipahami dengan beberapa menu diantaranya menu berita kegiatan, menu gallery foto, dan menu video dokumen.

2. Bentuk penyampain aktivitas yang dilakukan Program Studi Teknik Informatika ke kalangan masyarakat. Berupa penyampaian berita kegiatan yang dilakukan Fakultas Teknik dalam bentuk foto dan video dokumentasi bahwa Program Studi Teknik Informatika merupakan salah satu Fakultas yang akif.

3. Proses dokumentasi dari aktivitas Fakultas Teknik Program Studi Teknik Informatika yang diterapkan oleh Program Studi Teknik Informatika berupa Foto dan video yang dapat diakses secara online.

\section{DAFTAR PUSTAKA}

[1] Achmad Solichin, 2010. "Mysql 5 Dari Pemulah hingga Mahir". Universitas Budi Luhur. Jakarta.

[2] Abbdul Kadir, 2014. Pengenalan Sistem Informasi Edisi Revisi. Yogyakarta : Penerbit Andi.

[3] Agung Wahana, Asep Ririh Riswaya, 2014. "Perancangan Aplikasi Pengolahan Data Report Penjualan". Jurnal Computech \& Bisnis. Vol. 8, No. 1, 1-10.

[4] Al-Bahra Bin Ladjamudin, 2015. Analisi dan Desain Sistem Informasi. Yogyakarta : Penerbit Andi.

[5] Anastasia Lipursari, 2013. "Peran Sistem Informasi Manajemen (SIM) Dalam Pengambilan Keputusan". Jurnal STIE SEMARANG. VOL, NO 1.

[6] Cecep Lupi Hepyan, Erwin Gunadhi, Rina Kurniawati, 2012. "Rekayasa Perangkat Lunak Aplikasi Penjualan Obat Pada Apotek Mulya Abadi”. Jurnal Algoritma. Vol. 9, No. 43.

[7] Dini hariyati, Ricky Akbar, dan Meza Silvana, 2017. "Pembangunan Sistem Informasi Rawat Jalan Berbasis Web 
dengan Fitur Mobile pada Puskesmas Tarok Kota Payakumbuh”. Jurnal TEKNOSI. Vol.3, No.3.

[8] Dani Eko Hendrianto. 2014. "Pembuatan Sitem Informasi Perpustakaan Berbasis Website Pada Sekolah Menengah Pertama Negeri 1 Donorojo Kabupaten Pacitan”. Jurnal Indonesian On Networking and Security. Vol. 3, No. 4.

[9] Elly Warni dan Adi Wahyudi P, 2011. "Rekayasa Perangkat Lunak Aplikasi Penjualan Obat Pada Apotek Mulya Abadi”. Prosiding. Vol. 5, No. 3.

[10] Harison, Ahmad Syarif, 2016. "Sistem Informasi Geografis Sarana Pada Kabupaten Pasaman Barat”. Jurnal TEKNOIF. Vol. 4, No. 2.

[11] Heni Handayani, 2014. “XAMPP”. Jurnal Ilmuti.

[12] Lukman Gozali, Erwin Gunadhi, Rina Kurniawati, 2012. "Perancangan Sistem Informasi Penjualan Buku Pada Pd. Restu Percetakan”. Jurnal Algoritma. Vol. 9, No. 25.

[13] Muhdar Abdurahman, 2016. "Sistem Informasi Jadwal Perkuliahan Berbasis Web Mobile Pada Politeknik Sains Dan Teknologi Wiratama Maluku Utara”. Journal on Networking and Security. Vol. 5, No. 2.

[14] Ni Wayan Sumartini Sarawati, 2017. "Sistem Pengolahan Data Dosen Tetap STMIK STIKOM Indonesia Berbasis Web”. Jurnal Teknologi Informasi dan Komputer. Vol. 3, No. 1.

[15] Rajib Abi Bakri, 2013." Sistem Lelang Online Berbasis Web". Jurnal Rekayasa dan Teknologi Elektro. Vol 7, No. 3.

[16] Riska Audina, 2015. "Aplikasi Informasi Kegiatan Mahasiswa di Fakultas Ilmu Terapan Uniiversitas Telkom Berbasis Android dan SMS Broadcast". eProceeding of Applied Science : Vol.1, No.3.

[17] Rosa A.S, 2013. Rekayasa Perangkat Lunak Terstruktur Dan Beriorientasi Objek. Penerbit : Informatika. Bandung.

[18] Tata Sutabri, 2012. Analisis Sistem Informasi. Yogyakarta : Penerbit Andi.

[19] Yuhendra, M.T, Dr. Eng, Riza Eko Yulianto, 2015. "Rekayasa Perangkat Lunak Pengolahan Data Distribusi Obatobatan Di PT. Anugrah Pharmindo
Lestari Berbasis Web". Jurnal Momentum. Vol. 17, No. 2.

[20] Yadi Utama, 2011. "Sistem Informasi Berbasis Web Jurusan Sistem Informasi Fakultas Ilmu Komputer Universitas Sriwijaya”. Jurnal Sistem Informasi. Vol. 3. No 2 .

[21] Dikutip dari : http://lusisyafrina27 .weebly.com/sejarah.html. Diakses 21-04-2018, AM 10.00. 